extending for a distance of four miles and doing damage estimated at about $£ 200,000$. Fire broke out, too, at Louisville (Kentucky) where martial law had to be proclaimed, as also at Columbus (Ohio). The sufferings of the homeless are increased by inclement weather conditions, with intense cold, snow and sleet. President Roosevelt has issued a proclamation stating that it is imperative to raise a fund of at least $£ 400,000$ to relieve the destitution of the victims.

\section{Flooding in Southern England}

THE catastrophic experience in the United States is reflected in a minor degree in the southern counties of England, where persistent rains have caused inundations in Kent, Sussex, Berkshire, Wiltshire, Northamptonshire, Bedfordshire and elsewhere. The valley of the Thames in many places is under water and the river is running more than 'bank high', the rate of flow having reached 8,700 million gallons per 24 hour day, as compared with the 9,000 million gallons recorded on January 3 last year, during a period of exceptionally heavy rainfall. The standard daily average for the month of January is 2,407 million gallons. Although the latest indications are that the peak level has been passed, yet, with an outlook presaging more rain in all districts, the prospects of an early subsidence of the flood. waters are by no means reassuring, and much discomfort to marooned residents and interference with road traffic is being experienced.

\section{Leopold von Schrötter (I837-I908)}

A commrtees of prominent Viennese physicians and laryngologists has recently been formed to commemorate the centenary of the birth of the man, equally illustrious as laryngologist and physician, whose fullname and titles were Hofrat Prof. Dr. Leopold Ritter Schrötter von Kristelli. He was born at Graz on February 5, 1837, the son of the eminent chemist who discovered amorphous phosphorus. He studied medicine at Vienna, where he qualified in 1861. From an early stage in his career he took a keen interest not only in diseases of the chest, which he had an unrivalled opportunity of studying under Prof. Skoda, the great authority on this subject, but also in laryngoscopy, the importance of which to the physician he was the first to emphasize. During his subsequent career he occupied the important positions of director of the first laryngological clinic to be established and later the chair of clinical medicine in the University of Vienna. His principal work was a book on diseases of the larynx, trachea, nose and throat, which for a long time was the standard publication on this subject. He also contributed important articles to various systems of medicine on diseases of the heart and pericardium and syphilis of the larynx. Lastly, he deserves recognition as being one of the first to introduce sanatoria for the treatment of pulmonary tuberculosis, and to combat the pessimistic outlook of the medical profession regarding the cure of this disease. His death took place on April 22, 1908.

\section{Severance of Britain and the Continent}

IN another column of this issue of NATuRE (see p. 200) there appears a brief account of an archæological investigation of the submerged land-surface of the Essex coast by a sub-committee of the Fenland Research Committee. Questions of land elevation and submergence are naturally of much interest to prehistorians, more especially in relation to questions of dating, as well as of the possibilities and means of contact and communication between early cultures and peoples. One of the most important of such inquiries is that of the period at which separation of Britain from the Continent took place. In the same issue of the Proceedings of the Prehistoric Society in which the report on the submerged area of the Essex coast appears, Mr. Philip Ullyott, of the Department of Zoology, Cambridge, opens up a new line of evidence for dating this severance in "A Note on the Zoogeographical History of North-western Europe". In this he examines the geographical distribution of certain types of flat-worms (planarians) belonging to the same group and living in fresh-water, but adapted to different temperature ranges. His conclusion, in brief, is that the distribution of these types suggests that Britain must have separated from the Continent after the average summer temperature had exceeded $12^{\circ} \mathrm{C}$., but before it had reached more than $16^{\circ} \mathrm{C}$.

Thanks to the studies of Scandinavian workers, the curve of mean summer temperature during postglacial time is known fairly accurately. It is, therefore, possible to say that the breaking of the land surface, across which the flat-worms migrated in fresh-water from the Continent to Britain, must have occurred during the Boreal period, but before its later stage, when the temperature curve rose to its maximum during post-glacial time. This conclusion agrees remarkably closely with the evidence of palæobotanical investigation, which points to an early Boreal phase, c. $6800-5000$ B.c. As is pointed out in an editorial note, there is archæological support for this dating in the close connexion of the Baltic and Britain in the Continental period, while certain types become infrequent in Britain in the late Boreal period, and by Atlantic times the forest culture of south-east Britain had become quite distinct from the Ertebölle of Denmark and Schleswig-Holstein.

\section{Snow}

In his Friday evening discourse at the Royal Institution on January 22, Mr. Gerald Seligman discussed "The Nature of Snow". He commenced by showing how the molecular structure of ice accounts for the hexagonal structure of ice crystals. He reproduced Tyndall's experiment of forming 'negative crystals' in ice by passing a beam of light through it. A cinematographic reproduction of the same experiment showed the formation of these 'crystals' under high magnification. Ice evaporation is stimulated by a comparatively high temperature, and the reverse process-reconsolidation-by a low temperature. Mr. Seligman stressed the importance of sublimation in every question affecting snow and snowcraft. The life-histories of different types of 